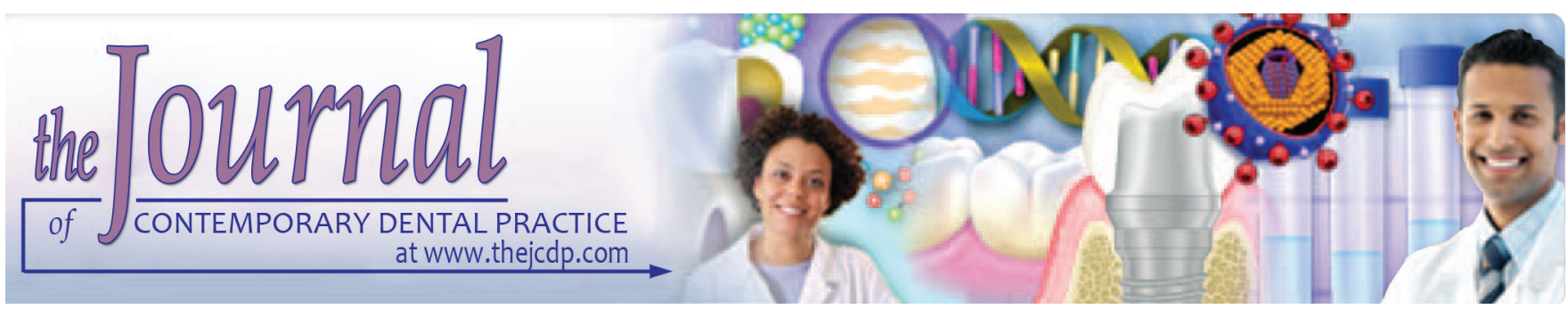

\title{
Cephalometric Soft Tissue Standard and Gender Dimorphism in Nasal Prominence estimated By Holdaway's Analysis in Patients visiting College of Dentistry, Aljouf University
}

Ibadullah Kundi

\begin{abstract}
Introduction: The objectives were to see the nasal prominence norm and the gender dimorphism in nasal prominence measured by Holdaway's soft tissue analysis.
\end{abstract}

Materials and methods: The sample size was 100 (50 males and 50 females). The subjects included in the study were of Saudi origin with class I skeletal and dental relationship and all teeth present. The age group of the patients was between 18 and 28 years. The radiographs were traced and analyzed by two students and cross-checked by an orthodontist. The nasal prominence was measured according to the technique described by Holdaway.

Results: The descriptive statistics were calculated for both male and female groups. The mean value of nasal prominence when male and female samples were combined was $14.08 \mathrm{~mm}$. No statistically significant difference was found $(p=0.083)$ when genders were compared. The level of significance was set at $p<0.05$.

Conclusion: No statistically significant difference was found when genders were compared. The value for males was normal while the value for females was less than Holdaway's normal.

Clinical significance: These values would aid in treatment planning for orthognathic surgery and orthodontic treatment.

Keywords: Cephalometrics, Holdaway's soft tissue analysis, Nose Prominence.

How to cite this article: Kundi I. Cephalometric Soft Tissue Standard and Gender Dimorphism in Nasal Prominence estimated by Holdaway's Analysis in Patients visiting College of

Department of Orthodontics, College of Dentistry, Aljouf University, Sakakah, Al-Jawf, Kingdom of Saudi Arabia

Corresponding Author: Ibadullah Kundi, Department of Orthodontics, College of Dentistry, Aljouf University, Sakakah Al-Jawf, Kingdom of Saudi Arabia, e-mail: dr.ibadullah.kundi@ judent.org
Dentistry, Aljouf University. J Contemp Dent Pract 2017; 18(2):152-155.

Source of support: Nil

Conflict of interest: None

\section{INTRODUCTION}

For overall appearance and facial esthetics of a person, nose and midface are very important. ${ }^{1}$ Nasal growth is completed in girls at the age of 16 and in boys at the age of approximately 18 years, while some studies suggest this development continues into the adult age. Esthetic nasal surgery is becoming common and popular in today's world. ${ }^{2,3}$ Recently, the studies being carried out have put the concept of "divine proportion" into question by confirming race- and gender-specific soft tissue cephalometric norms and by proving that the standards of beauty change from region-to-region. ${ }^{4}$ The nose shape has been classified according to regions with blacks having platyrrhine-, oriental's mesorrhine-, and whites having leptorrhine-shaped noses. ${ }^{5}$ The standards of nasal parameters can be used as a standard for comparing treatment outcomes, treatment planning in orthodontics, and nasal surgeries. ${ }^{6}$ Nasal norms can be measured by direct clinical measurement (morphometric), lateral cephalograms, two-dimensional ${ }^{8}$ and three-dimensional (3D) ${ }^{6}$ photographs, 3D white light scanners, ${ }^{9}$ and 3D laser scans. ${ }^{10}$

The rationale of performing of this study is to have population-specific values of nasal length, which could assist us in orthodontic and orthognathic surgery treatment planning of the Saudi population.

\section{Objectives}

The objectives of the study are to see the nasal prominence norm and gender dimorphism measured by 
cephalometric Holdaway's soft tissue analysis in patients visiting the College of Dentistry, Aljouf University, Al-Jawf , Kingdom of Saudi Arabia.

\section{MATERIALS AND METHODS}

The cross-sectional descriptive study was conducted in patients visiting the College of Dentistry, Aljouf University, Al-Jawf, Kingdom of Saudi Arabia. Ethical approval was obtained from the hospital, and every patient's confidentiality was assured. The duration of the study was 8 months from 1st Octuber 2015 to 31th May 2016. The sample size was 100 ( 50 males and 50 females). The radiographs were analyzed by students and crosschecked by an orthodontist. The $2 \mathrm{H}$ pencil was used to draw the tangents. Cephalometric images were acquired with a Cranex D digital X-ray unit, Version 3 (Soredex Co., Tuusula, Finland). The $73 \mathrm{kVp}$ for lateral cephalometric radiograph was used. About 20 seconds exposure time was selected through $2.7 \mathrm{~mm}$ Al filtration for both types of radiographs. Two experienced orthodontists analyzed clinically the radiographs for high quality and sharpness. Patients having history of trauma, previous facial/ mandibular surgery, syndromes (affecting face/jaw), and incomplete records were excluded. Approval on the study design from the local ethical committee of the College of Dentistry, Aljouf University, Al-Jawf, Kingdom of Saudi Arabia, was obtained.

The subjects included in the study were of Saudi origin with class I skeletal and dental relationship and all teeth were present (except the third molars). Cases with anomalies, e.g., trauma, surgery, and scars were excluded.

\section{Data Collection}

The age group of the patients was between 18 and 28 years. The radiographs were traced and analyzed by two orthodontists. The tracing was carried out with a $2 \mathrm{H}$ pencil. The nasal prominence was measured according to the technique described by Holdaway (Fig. 1). The nasal length is described as the distance from a line perpendicular to the Frankfort horizontal and running tangent to the vermillion border of the upper lip, to the tip of the nose. ${ }^{11,12}$ The linear measurement was made with a graduated metric ruler to the nearest of $0.5 \mathrm{~mm}$. Data were analyzed using Statistical Package for the Social Sciences version 20 using Student's t-test. The level of significance was set at $\mathrm{p}<0.05$.

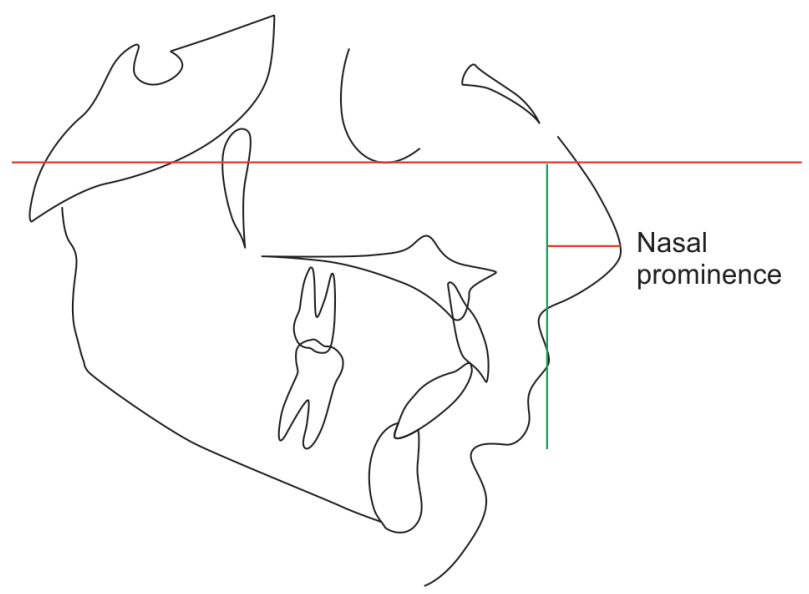

Fig. 1: The nasal prominence evaluated using Holdaway's analysis

Table 1: Mean and standard deviations of nasal prominence for male and female patients measured from lateral cephalometric radiographs

\begin{tabular}{lllll}
\hline & Mean & $n$ & $S D$ & Standard error mean \\
\hline M length & 15.1200 & 100 & 4.76375 & 0.95275 \\
F length & 13.0400 & 100 & 2.42350 & 0.48470 \\
\hline
\end{tabular}

SD: Standard deviation

\section{RESULTS}

The mean nasal length value was $15.12 \pm 4.8 \mathrm{~mm}$ for male patients and $13.04 \pm 2.4 \mathrm{~mm}$ for female patients (Table 1). The mean value of nasal prominence when male and female samples were combined was $14.08 \mathrm{~mm}$. No significant difference $(\mathrm{p}=0.083)$ was noticed in nasal lengths between male and female patients (Table 2).

\section{DISCUSSION}

The aim of the orthodontic treatment is to improve the facial esthetics of the patients. ${ }^{13}$ Albrecht Durer maintained that disproportionate faces are unesthetic and proportionate faces acceptable, if not considered beautiful. ${ }^{14}$ According to studies, the growth of nose is in a downward and forward direction with increase in length of $1.5 \mathrm{~mm}$ every year. ${ }^{15}$ It has been confirmed that hard tissues (i.e., nasal bones) and ligaments determine the shape of the nose. ${ }^{16}$ Like all other parts of the face, nasal features are characteristic of every individual and region. ${ }^{17}$

Nasal length decreased from $18.2 \mathrm{~mm}$ [standard deviation $(\mathrm{SD})=3.5$ ] to $16.5 \mathrm{~mm}(\mathrm{SD}=3.3)$ in skeletally class III patients who underwent both Le Fort class I and bilateral sagittal split osteotomy. ${ }^{18}$ Patients with vertical maxillary excess have increased nasal lengths. ${ }^{19}$ Noses become more

Table 2: Gender differences for mean and SD of cephalometric measurements of nasal prominence for Saudi subjects $(n=50)$

\begin{tabular}{|c|c|c|c|c|c|c|c|c|}
\hline & \multicolumn{5}{|c|}{ Paired differences } & \multirow[b]{3}{*}{$T$} & \multirow[b]{3}{*}{$d f$} & \multirow[b]{3}{*}{ Sig. (two-tailed) } \\
\hline & \multirow[b]{2}{*}{ Mean } & \multirow[b]{2}{*}{$S D$} & \multirow[b]{2}{*}{ Standard error mean } & \multicolumn{2}{|c|}{$95 \%$ Confidence interval of the difference } & & & \\
\hline & & & & Lower & Upper & & & \\
\hline Male-female & 2.08 & 5.75123 & 1.15025 & -0.29399 & 4.45399 & 1.808 & 99 & 0.083 \\
\hline
\end{tabular}

SD: Standard deviation 
Table 3: A comparison of the nose prominence recorded in this study with that reported for other populations by different authors

\begin{tabular}{|c|c|c|c|}
\hline Authors & $\begin{array}{l}\text { Year of } \\
\text { publication }\end{array}$ & $\begin{array}{l}\text { Population } \\
\text { studied }\end{array}$ & $\begin{array}{l}\text { Nasal prominence } \\
\text { in } \mathrm{mm}\end{array}$ \\
\hline Holdaway ${ }^{25}$ & 1983 & Caucasian & 14-24 \\
\hline Lew et $\mathrm{al}^{28}$ & 1992 & Chinese & 6.00 \\
\hline Alcalde et $\mathrm{al}^{26}$ & 2000 & Japanese & 14.54 \\
\hline Basciftci et al ${ }^{29}$ & 2003 & Turkish & 18.74 \\
\hline Al-Gunaid et al ${ }^{30}$ & 2007 & Yemeni males & 16.70 \\
\hline Hameed et $\mathrm{al}^{31}$ & 2008 & Pakistanis & 19.36 \\
\hline Al-Azemi et al ${ }^{27}$ & 2008 & Kuwaitis & 14.25 \\
\hline Taki et al ${ }^{24}$ & 2009 & Persian adults & 16.72 \\
\hline Mehta et al ${ }^{32}$ & 2010 & Indians & 13.38 \\
\hline Hussein et $\mathrm{al}^{22}$ & 2011 & Palestinians & 19.24 \\
\hline Present study & 2016 & Saudi Arabians & 14.08 \\
\hline
\end{tabular}

prominent (anesthetic) in patients who undergo maxillary first premolar extraction in skeletally class II cases, and had lengthy noses in the beginning of treatment.

The nasal prominence measured in the United States of America according to the Burlington growth study in males was $15 \mathrm{~mm}$ and in females, it was $14 \mathrm{~mm} \cdot{ }^{20} \mathrm{In}$ India, in the Lambada population in the Telangana region of Andhra Pradesh, males had lengths of $3.9 \pm 1.2$ and females exhibited lengths of $3.8 \pm 0.99 .{ }^{21}$ The Palestinian population exhibited length of $19.24 \pm 3.01{ }^{22}$ Turkish population displayed lengths of $15.3 \pm 3.4 \mathrm{~mm}$ in males and $15.3 \pm 2.8 \mathrm{~mm}$ in females. ${ }^{23}$ Persian males had a length of $18.91 \pm 2.97$ and $14.91 \pm 2.90 \mathrm{~mm} .{ }^{24}$ The values obtained from our study for males $(15+4.8 \mathrm{~mm})$ were in the normal range as described by Holdaway $(14-24 \mathrm{~mm}){ }_{,}^{25}$ while the females nasal length obtained was less than the normal value. The length obtained from our study was similar to Caucasian, ${ }^{25}$ Japenese, ${ }^{26}$ and Kuwaitis ${ }^{27}$ population (Table 3). ${ }^{28-32}$

A limitation of Holdaway's nose prominence, as a soft tissue cephalometric parameter for assessing the nasal profile is that although it is relatively easy to measure, it does not provide a detailed cephalometric analysis of the nose. The other limitation of this value is that it is influenced by the soft tissue point labrale superioris, which is influenced immensely by the facio palatal inclination of the teeth; hence, we should consider other cephalometric values for measuring the length of the nose that are not to be influenced by the dentition.

\section{CONCLUSION}

- No statistically significant difference was found when genders were compared for nasal prominence.

- The value for males was normal while the value for females was less than Holdaway's normal.

- The mean value of nasal prominence for both male and female sample was within the range of Holdaway's normal.

\section{REFERENCES}

1. O'Ryan F, Schendel S. Nasal anatomy and maxillary surgery. I. Esthetic and anatomic principles. Int J Adult Orthodon Orthognath Surg 1989;4(1):27-37.

2. Davis RE. Nasal tip complications. Facial Plast Surg 2012 Jun;28(3):294-302.

3. Kim SH, Whang E, Choi HG, Shin DH, Uhm KI, Chung H, Song WC, Koh KS. Analysis of the midface, focusing on the nose: an anthropometric study in young Koreans. J Craniofac Surg 2010 Nov;21(6):1941-1944.

4. Szychta P, Rykala J, Kruk-Jeromin J. Individual and ethnic aspects of preoperative planning for posttraumatic rhinoplasty. Eur J Plast Surg 2011 Aug;34(4):245-249.

5. Abraham MT, Romo T. Rhinoplasty multiracial, otolaryngology and facia. Plast Surg 2006;1(11).

6. Jayaratne YS, Deutsch CK, Zwahlen RA. A3D anthropometric analysis of the orolabial region in Chinese young adults. Br J Oral Maxillofac Surg 2013 Dec;51(8):908-912.

7. Starck WJ, Epker BN. Cephalometric analysis of profile nasal esthetics. Part I. Method and normative data. Int J Adult Orthodon Orthognath Surg 1996;11(2):91-103.

8. Jimoh RO, Alabi SB, Kayode AS, Salihu AM, Ogidi OD. Rhinometry: spectrum of nasal profile among Nigerian Africans. Braz J Otorhinolaryngol 2011 Sep-Oct;77(5):589-593.

9. Antoun JS, Lawrence C, Leow A, Rongo R, Dias G, Farella M. A three-dimensional evaluation of Māori and New Zealand European faces. Aust Orthod J 2014 Nov;30(2):169-175.

10. Aung SC, Foo CL, Lee ST. Three dimensional laser scan assessment of the Oriental nose with a new classification of Oriental nasal types. Br J Plast Surg 2000 Mar;53(2):109-116.

11. Sahin Sağlam AM. Holdaway measurement norms in Turkish adults. Quintessence Int 2002 Nov-Dec;33(10):757-762.

12. Isiekwe GI, daCosta OO, Utomi IL, Sanu OO. Holdaway's analysis of the nose prominence of an adult Nigerian population. Niger J Clin Pract 2015 Jul-Aug;18(4):548-552.

13. Subtelny JD. The soft tissue profile, growth and treatment changes. Angle Orthod 1961 Apr;31(2):105-122.

14. Dürer, A. The art of measurement. San Francsco: Alan Wofsy Fine Arts; 1981.

15. Wisth PJ. Nose morphology in individuals with Angle Class I, Class II or Class III occlusions. Acta Odontol Scand 1975;33(1):53-57.

16. Milton NA. Quantitative method for the evaluation of the soft-tissue facial profile. Am J Orthod 1959 Oct;45(10):738-751.

17. Nehra K, Sharma V. Nasal morphology as an indicator of vertical maxillary skeletal pattern. J Orthod 2009 Sep;36(3):160-166.

18. Ghassemi M, Ghassemi A, Showkatbakhsh R, Ahmad SS, Shadab M, Modabber A, Jamilian A. Evaluation of soft and hard tissue changes after bimaxillary surgery in class III orthognathic surgery and aesthetic consideration. Natl J Maxillofac Surg 2014 Jul-Dec;5(2):157-160.

19. de Assis EA, Starck WJ, Epker BN. Cephalometric analysis of profile nasal esthetics. Part II. Patients with vertical maxillary excess. Int J Adult Orthodon Orthognath Surg 1996;11(3):205-210.

20. Bergman RT, Waschak J, Borzabadi-Farahani A, Murphy NC. Longitudinal study of cephalometric soft tissue profile traits between the ages of 6 and 18 years. Angle Orthod 2014 Jan;84(1):48-55.

21. Thomas M, Reddy VD, Lakshmi HV. Soft-tissue cephalometric norms for the Lambada population in Telangana 
Region of Andhra Pradesh. Indian J Dent Res 2012 May-Jun;23(3):353-358.

22. Hussein E, Khateeb SA, Watted N, Aksoy A, Acar A, Abu Mowais M. Evaluation of facial soft tissue parameters for Palestinians using Holdaway analysis. Saudi Dent J 2011 Oct;23(4):191-195.

23. Uysal T, Baysal A, Yagci A, Sigler LM, McNamara JA Jr. Ethnic differences in the soft tissue profiles of Turkish and European-American young adults with normal occlusions and well-balanced faces. Eur J Orthod 2012 Jun;34(3):296-301.

24. Taki AA, Oguz F, Abuhijleh E. Facial soft tissue values in Persian adults with normal occlusion and well-balanced faces. Angle Orthod 2009 May;79(3):491-494.

25. Holdaway RA. A soft-tissue cephalometric analysis and its use in orthodontic treatment planning. Part I. Am J Orthod 1983 Jul;84(1):1-28.

26. Alcalde RE, Jinno T, Orsini MG, Sasaki A, Sugiyama RM, Matsumura T. Soft tissue cephalometric norms in Japanese adults. Am J Orthod Dentofacial Orthop 2000 Jul;118(1):84-89.
27. Al-Azemi R, Al-Jame B, Artun J. Lateral cephalometric norms for adolescent Kuwaitis: soft tissue measurements. Med Princ Pract 2008;17(3):215-220.

28. Lew KK, Ho KK, Keng SB, Ho KH. Soft-tissue cephalometric norms in Chinese adults with esthetic facial profiles. J Oral Maxillofac Surg 1992 Nov;50(11):1184-1189.

29. Basciftci FA, Uysal T, Buyukerkmen A. Determination of Holdaway soft tissue norms in Anatolian Turkish adults. Am J Orthod Dentofacial Orthop 2003 Apr;123(4):395-400.

30. Al-Gunaid T, Yamada K, Yamaki M, Saito I. Soft-tissue cephalometric norms in Yemeni men. Am J Orthod Dentofacial Orthop 2007 Nov;132(5):576.e7-576.e14.

31. Hameed A, Khan JI, Ijaz A. Soft tissue facial profile analysis in patients with class I and class II skeletal pattern, visiting children's hospital, Lahore, Pakistan. Pak Oral Dent J 2008;28(2):183-188.

32. Mehta P, Kumar M, Goel M, Koshy S. Holdaway's soft tissue cephalometric norms for the population of Lucknow, India. J Oral Health Research 2010 Dec;1(4):153-159. 